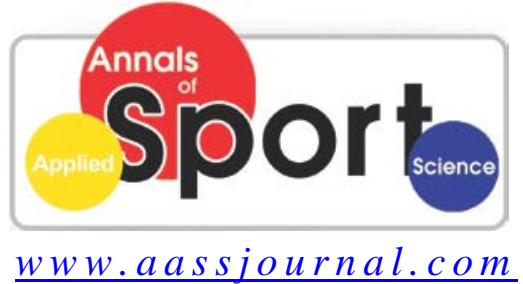

ISSN (Online): $2322-4479$

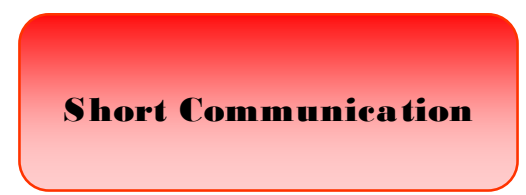

Received: 17/07/2013

Accepted: 03/01/2014

\title{
The Communication Skills as Selection Criteria of Iranian National Table Tennis Coach: Sport Elites Perspectives
}

\section{${ }^{1}$ Tahereh Rahmati ${ }^{*}{ }^{2}$ Mehrzad Hamidi, ${ }^{3}$ Habib Honari}

1. Department of Physical Education and Sport Sciences, International Campus of Tehran University, Karaj, Iran.

2. Department of Sport Management, Faculty of Physical Education and Sport Sciences, Tehran University, Tehran, Iran.

3. Department of Sport Management, Faculty of Physical Education and Sport Sciences, Allameh Tabataba'i University, Tehran, Iran.

\section{ABSTRACT}

The purpose of this study was to determine the prioritization and comparison of communication skills as a selection criterion of Iran's national table tennis coach from the sport elites perspectives. As this was a descriptive study, survey methodology was employed. The study population consisted of 100 table tennis sport elites of whom 80 subjects were randomly selected using the Morgan table. Questionnaires designed for the study consisted of 15 items. To determine the reliability of the questionnaire, Cronbach's alpha was used. McLean and Zakrajsk model was used in examining communication skills as a selection criterion of Iran's national table tennis coach. Results of this study indicate that there is no difference among the participants in prioritizing communication skills as a criterion $(\mathrm{P}>0.05)$.

Key Words: Coaching, Communication Skills, Table Tennis.

Corresponding Author:

Tahereh Rahmati

E-mail: taherehrahmati20@gmail.com 


\section{INTRODUCTION}

communication skills is one of the evaluation and selection criteria for national coach (1), as the previous studies revealed that one of the important factors for coaches selection in some Iranian national teams such as swimming, diving, water polo (2), and handball (3) was communication skills with others (athletes, coaches, referees, team leader) including emotion (2), oratory and eloquence (1).

In an article on the psychology of coaching, Spink (1991) refers to a coach's communication skills as his ability to transmit messages and concepts to athletes and bilateral relationship between them (4). Kinlaw (1997) considers feedback as one of a coach's characteristics (5). Smith and Smoll (1997) believe that the coach-athlete relationship is an important determinant in creating a healthy sport environment (6).

McCann (2001), a member of America National Olympic Committee's Department of Psychology, believes that three key factors including knowledge and personal information, capabilities for controlling the emotional factors affecting an athlete, and having a strong and effective relationship with athletes can cause success or failure of coaches (7). Everybody who works in high level sports, such as coaches, referees, managers, parents amongst others are also a very important part to study due to the fact that their psychological characteristics may affect performance $(8,9)$. Coaches must improve their abilities and skills through a successful control of their psychological variables so that they can develop the appropriate skills to accomplish the best sporting results from their athletes (8). The coach-athlete relationship is an important determinant in this system. Establishing goals, setting priorities and understanding the values (both appropriate and inappropriate) placed on winning, fun and development are areas that coaches have the potential to both directly and indirectly influence the sporting experience. The most influential coaches are not only well-versed in the tactical and technical components of their sport, they understand the role that communication, sport management, sound pedagogical skills, liability, first aid, physiology and mental skills training have on the sporting experience of their athletes (8). ITF coaching program in 2007 consists of the following: A good coach should be a good communicator. The very essence of coaching is communication. Coach-Player communication: Why is it important? It conveys information, influences motivation and provides feedback in learning. Types of communication: Verbal and Nonverbal. Verbal communication includes: Talking, asking, giving feedback, giving rewards, listening and receiving feedback. Nonverbal communication includes: Facial expression, gestures, body movements, body posture, body contact, spatial awareness, clothes and appearance (10). Nash (2008) reported that to be successful in coaching, you must be able to effectively communicate with your players, parents, other coaches and officials. Good communication skills arise from constantly making an effort to become a better communicator. The keys to becoming an effective communicator are being able to communicate openly, positively and clearly (11). Khooran, Khabiri and Ehsani (2008) reported a positive relation between leadership behaviors realized by Athlete (exercise and training, democratic behavior, social support and positive feedback) with Athlete's satisfaction, but they did not observe a meaningful relation between leader's despotic behaviours and other satisfaction indexes (12). D'Amato and Hannum (2009) reported to offer an indepth look at how coaching is practiced in organizations today and what skills and business processes can most positively have an effect when implemented in a thoughtful 
and efficient way (13). As demonstrated by the detailed survey data and particularly the importance/effectiveness of scatter plot analysis, while current coaching programs are addressing certain valuable business skills like stronger communication, building bench strength and increasing conflict management, there are other critical needs that are not being addressed (13). MacAfee (2007) a member of table tennis coaches association of America said: “Today's educators must be familiar with psychology techniques to practice" (14). The Human Capital Institute et al. (2012) said: "Coaching can be a critical way to build executive presence and interpersonal skills. This is especially important for leaders in technical roles. They have a lot of knowledge, but may struggle to guide others and listen and internalize feedback. It not an issue of performance, but about how coaching can help these individuals develop their leadership skills" (15). Joo B-K, Sushko, and McLean (2012) said: “Today, it is more important than ever to establish and support strong leadership at every level in an organization. Intangible skills like communication and conflict management are the keys to success in this environment and coaching is an efficient method to address such challenges. Coaching can be targeted to address any development need or problem solving that is required and it is this adaptability that makes it particularly effective (16). The Human Capital Institute et al. (2012) said: “Coaching as a leadership skill has become vital as managers need to develop employees, retain key talent, build productive teams and influence change" (15). Otis (2013) indicates that coaches (leaders) communicate to: command others, resolve conflicts, express oneself, Persuasion and Influence and share information (17).

Given the importance of coaching and selecting a qualified coach in the success of sports teams, having coaching selection criteria will help in choosing the right people. To resolve this problem, identifying criteria for selecting coaches seems necessary. It can be seen that one of the main criteria for selecting a coach is communication skills. Thus this study aims to prioritize communication skills as a criterion to select the best coach.

\section{MATERIALS AND METHODS}

Participants. 80 elites of table tennis from 100 elites were randomly selected as sample thus 20 people from Directors (board members, federation committees' directors, and the board of table tennis; 10 people consisting coaches of adult, youth and adolescent national teams (2001-2011); 30 people consisting of youth and adult national athletes (2001-2011); 20 people consisting of the sport's pioneers (championship level managers who had experience in executive activities or degree of national and international tennis coaching).

Tools. Based on literature review and experts' views research questions were formulated. The questionnaire, with 15 items was prepared to elicit response for communication skills as a criterion in determining Iran's national table tennis team's coach. Likert scale was selected for measuring the degree of importance of each item with each criterion having 5 as the highest value and 1 as the lowest values from low to high. Subjects read each item to determine how it is important to select the desired option. The views of 10 sports management professors were used to determine the content validity of the research. The questionnaires were distributed among 20 subjects to determine the reliability of the study; The Cronbach's alpha (0.968) was seen.

Statistical Analysis. The data were analyzed using both descriptive and inferential statistics. Descriptive statistics was used for demographic description while inferential statistics such as Friedman and 
ANOVA test was used for rating criteria and Kruskal-Wallis test for hypothesis testing. Data were analyzed using SPSS software. Statistical significance was set at $\mathrm{P}<0.05$.

\section{RESULTS}

The study sample was categorized in four groups included national athletes; national coaches, directors and pioneers. Descriptive indices of variables are given in Tables 1 and 2. The highest percentage frequency related to Bachelor's degree, degree in Physical Education, job, championship record, national team record, coaching record and international coaching degree (Table 2). As it can be seen in Tables 3 and 4, the highest rank is for "Alignment of coach's goals and interests with national and Federation interests" and the lowest rank is for "Familiarity with negotiation techniques and the ability to manage conflict (interpersonal conflict)".

Table 1. Descriptive indices of 4 groups of respondents

\begin{tabular}{ccc}
\hline Group & Frequency (F) & Percentage (P) \\
\hline National athlete & 30 & 37.5 \\
\hline National Coaches & 10 & 12.5 \\
\hline Directors & 20 & 25 \\
\hline Pioneers & 20 & 25 \\
\hline Total & 80 & 100 \\
\hline
\end{tabular}

Table 2. Descriptive indices of $\mathbf{4}$ groups of respondents according to demographic characteristics

\begin{tabular}{ccccccccccc}
\hline \multirow{2}{*}{ Sample } & \multicolumn{2}{c}{ players } & \multicolumn{3}{c}{ Coaches } & \multicolumn{2}{c}{ Directors } & pioneers & \multicolumn{2}{c}{ total } \\
\cline { 2 - 12 } & $\mathrm{F}$ & $\mathrm{P}$ & $\mathrm{F}$ & $\mathrm{P}$ & $\mathrm{F}$ & $\mathrm{P}$ & $\mathrm{F}$ & $\mathrm{P}$ & $\mathrm{F}$ & $\mathrm{P}$ \\
\hline Educated (B.A) & 11 & 37.9 & 5 & 50 & 8 & 40 & 10 & 50 & 34 & 44 \\
\hline Degree (Physical Education) & 17 & 56.7 & 7 & 70 & 9 & 47.4 & 8 & 40 & 41 & 51.9 \\
\hline Job (coach) & 7 & 41.2 & 8 & 80 & 11 & 61.1 & 10 & 50 & 36 & 55.4 \\
\hline Championship Record (below 10 years) & 18 & 60 & 2 & 28.6 & 6 & 42.9 & 6 & 50 & 32 & 50.8 \\
\hline National Team Record (below 10 years) & 24 & 80 & 4 & 57.1 & 9 & 81.8 & 6 & 75 & 43 & 76.8 \\
\hline Coaching Records (11-20 years) & 7 & 41.2 & 4 & 40 & 9 & 45 & 8 & 40 & 28 & 41.8 \\
\hline International coaching Degree & 4 & 21.1 & 6 & 60 & 10 & 50 & 7 & 35 & 27 & 39.1 \\
\hline
\end{tabular}

Table 3. Prioritization of the communication skill criteria from elite's perspectives

\begin{tabular}{lc}
\hline \multicolumn{1}{c}{ Communication Skill } & $\begin{array}{c}\text { Mean } \\
\text { rank }\end{array}$ \\
\hline 1- Alignment of coach's goals and interests with national and Federation interests & 9.26 \\
\hline 2-Ability to behavior fairly and free from discrimination with athletes & 8.83 \\
\hline 3-Active listening skills to understand the needs and problems of athletes and teams & 8.74 \\
\hline 4-Ability to speak clearly, honestly and effectively with athletes and administrators & 8.54 \\
\hline 5-Ability to use effective leadership style for individual athletes' & 8.49 \\
\hline 6-Taking advice, strategy, and feedback from others in coaching & 8.29 \\
\hline 7-Ability to create satisfying and joyful atmosphere in training & 8.26 \\
\hline 8-Ability to motivate athletes in training, practice and competition & 8.25 \\
\hline 9-Ability to understand and communicate using a common language and nonverbal cues with all athletes & 8.00 \\
\hline 10-Ability to handle the tough conditions of excitement and relaxation & 7.92 \\
\hline 11-Ability to create order and remind the players responsibilities in team & 7.80 \\
\hline 12-Ability to communicate regularly and effectively with others (colleagues, managers, staff, & 7.56 \\
fitness instructors and athletes) & 7.14 \\
\hline 13-Ability to provide constructive feedback to the athlete for the future development & 6.65 \\
\hline 14-Having a good relationship with the media & 6.29
\end{tabular}

Rahmati, T., Hamidi, M., Honari, H. (2015). Ann Appl Sport Sci, 3(2): 69-76. 
Table 4. Friedman test Statistics for prioritization of communication skill criteria

\begin{tabular}{cc}
\hline Chi-square & 81.871 \\
\hline Degree of freedom & 14 \\
\hline $\mathrm{p}$ & $0.001^{* *}$ \\
\hline \multirow{2}{**}{ : Significance level at $\mathrm{p}<0.01}$.
\end{tabular}

As it can be seen in Table 4, There is no significant difference among the participants in the prioritization of communication skills criteria $(\mathrm{P}>0.05)$.

Table 4- Kruskal-Wallis test for difference among the participants in the prioritization of communication skills criteria

\begin{tabular}{|c|c|c|c|c|c|}
\hline Population & Sample & Rating Average & Mean \pm SD & Chi-Square & $\mathbf{p}$ \\
\hline National Player & 30 & 36.67 & \multirow{4}{*}{$69.00 \pm 6.30$} & \multirow{4}{*}{2.146} & \multirow{4}{*}{0.543} \\
\hline National Coach & 10 & 42.45 & & & \\
\hline Directors & 20 & 46.18 & & & \\
\hline Pioneers & 20 & 39.60 & & & \\
\hline
\end{tabular}

\section{DISCUSSION and CONCLUSION}

Since the coach is the manager and uses the art and science of managing to manage a sports team, hetries to achieve success over a relatively long period of time. He uses all of his abilities; physical, mental, technical and expertise to manage and lead a sports team to bring about perfection of mental and physical skills of his players and to leads them to victory as a cohesive group/unit. He should be capable in all areas of physical, mental, technical, social and human aspects and use all elements of his existence in these areas to serve the sports organization.

Data obtained from previous researches on aspects of communication skills in coaching indicated that each of the criterions was necessary for success and performance of a coach (1-4).

The purpose of this study was to prioritize and compare communication skills as a selection criterion of Iran's national table tennis coach from the perspectives of sport elites. There was no consistent pattern for choosing suitable coach in the Federation; therefore it is recommended that this model can be used to choose a qualified coach in order of priority.

Results of this study indicate that there is no difference among the participants in the prioritization of communication skills criteria. Therefore, a unity pattern could be outlined to select national coaches.

The results of the study indicate that each criterion has separate and highly valued importance. Therefore, the researcher suggests that to achieve the desired criteria for communication skills in the selection of national team's coach, considering the priorities will achieve better results.

\section{APPLICABLE REMARKS}

- The most important criterion is Alignment of coach's goals and interests with national and Federation interests.

- A successful coach should primarily be aligned with the strategy and goals of the Federation and the national interest and eventually other criteria's. 


\section{REFFRENCES}

1. Hamidi M, Memari Z, Asghari M, Jafarabadi. The Dimensions And Criteria For The Selection Of Iranian National Coaches. Sport Management And Development. 2013;1(1):55-74 [Article in Farsi].

2. Shafiee M, Goudarzi M, Hamidi M, Yad Elahi J, Farsi. Determining And Modeling The National Coaches Selection In Swimming, Diving \& Water Polo In Coaches' Opinion. Harakat. 2007(32):19-36 [Article in Farsi].

3. Nasiri K, Khabiri M, Sajjadi N, Kazem Nezhad A. The Analysis and Modeling of an Evaluation for Handball National Team Coaches in Iran. Journal of Sport Management. 2009;1(1):119-40 [Article in Farsi].

4. Shafiei M, Goodarzi M. Determining National Coaches Selection Criteria in Swimming, Diving and Water Polo by Coaches' Viewpoints. World Journal of Sport Sciences. 2009;2(4):241-7.

5. Kinlaw DC. Coaching: Winning Strategies for Individuals and Teams: Gower; 1997. 190 p.

6. Smith RE, Smoll FL. Coaching the coaches: Youth sports as a scientific and applied behavioral setting. Current Directions in Psychological Science. 1997;6(1):16-21.

7. McCann S. So You Want To Be A Great “Big-Event Coach?” Three Things That Can Make or Break You. Olympic Coach. 2001;17(3):22-4.

8. Gimeno F, Castillo R, Marcen C. Psychological Skills Evolution During a Sport Season of Coaches of Women's Handball Teams. Procedia - Social and Behavioral Sciences. 2013;82:727-9.

9. Roberts G, Treasure D. Advances in motivation in sport and exercise: Human Kinetics; 2001.

10. ITF Coaching. Communication skills for the tennis coach (Coach Education Series-ITF Coaches Education Programme: Level 2 Coaching Course): International Tennis Federation; 2007. Available from: http://www.tennissa.co.za/images/Communication_0.pdf.

11. Nash S. Youth Basketball: Coaches Manual. Canada Basketball: Canada 2008.

12. Khooran H, Khabiri M, Ehsani S. Relation between Coaches' Different Behaviors from the Viewpoints of Athletes and level of athlete's Satisfaction. 1st National Congress of Sport Management: 20-year old document of Islamic Republic of Iran; Tehran, Iran: Iranian Olympic and Paralympics National Academy; 2008 [Article in Farsi].

13. D'Amato A, Hannum KM. In Focus/Retaining and Developing Talent-Generations talk about leaders and leadership development. Leadership in Action. 2009;29(3):20-1.

14. McAfee R. Sports Psychology For Table Tennis: Pro Table Tennis With Rowden Fullen; 2007 [cited 2014]. Available from: http://protabletennis.net/content/sports-psychology-table-tennis.

15. The Human Capital Institute, Harrison LH, Fakalata K, Wiete AK. Scaling Executive Coaching Across the Enterprise: The Key to Developing Tomorrow's Talent. Human Capital Institute (HCI), 2012 Contract No.: HCI SECAE 0113.

16. Joo B-K, Sushko JS, McLean GN. Multiple Faces of Coaching: Manager-as-coach, Executive Coaching, and Formal Mentoring. Organization Development Journal. 2012;30(1):19-40.

17. Otis E. Basic Communication Skills For Coaches NZ: Edmond Otis \& Associates, Inc., Edmond Otis \& Associates NZ, and AACT-NOW; 2013 [cited 2014]. Available from: http://www.softball.org.nz/site/softballnz/images/Development/Coaching/Sport\%20NZ\%20Conference/communi cation4coachesEdmondOtisLG.pdf. 
تازههاى علوم كاربردى ورزش

مقاله كوتاه

دوره سوم، شماره دوم

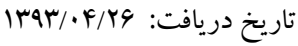

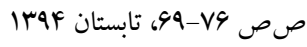

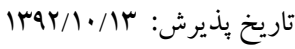

\section{مهارتهاى ارتباطى به عنوان معيار انتخاب مربيان تيمهاى ملى تنيس روى ميز كثور: از نظر نخبًان ورزشى 'طاهره رحمتى *، " مهرز اد حميدى، "حبيب هنرى}

I. دانشجوى دكترى مديريت ورزشى، يرديس بينالملل دانشخاه تهران، كرج، ايران.

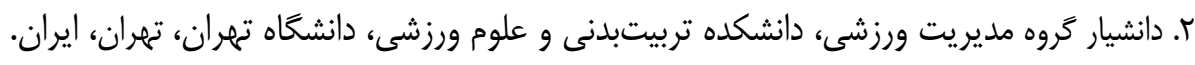

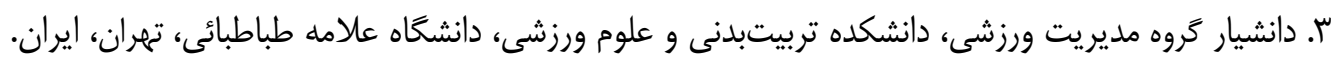

جكيده

هدف از اجراى اين تحقيق، اولويتبندى و مقايسه معيارهاى مهارت ارتباطى در انتخاب مربيان تيمهاى ملى تنيس روى ميز كشور از نظر

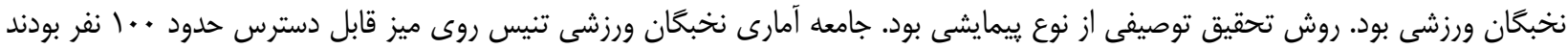

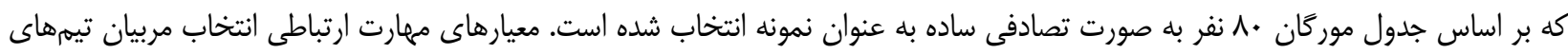

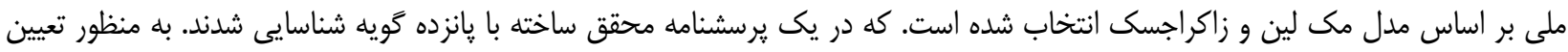

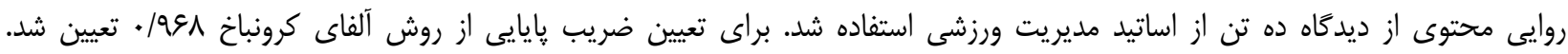

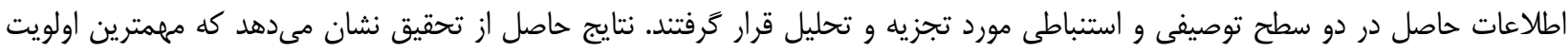

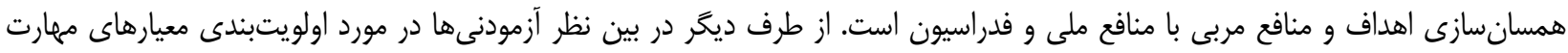

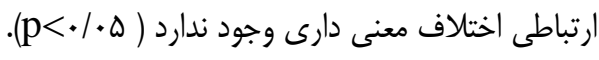
وازَّان كليدى: مربى، مهارتهاى ارتباطى، تنيس روى ميز.

"* - نوسنده مسئول:


